\title{
Biological and Animal Imagery in John Steinbeck's Migrant Agricultural Novels: A Re-evaluation
}

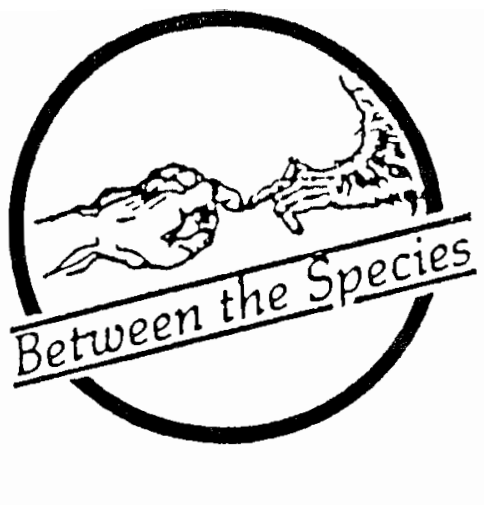

\author{
Josephine Levy \\ Tempe, Arizona
}

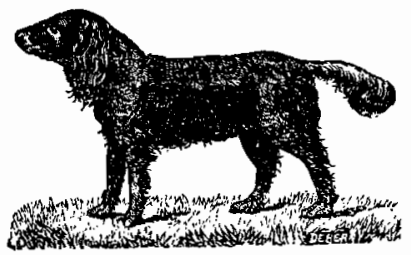

Critical reception of the work of John Steinbeck often makes note of that author's use of biological and animal imagery. Early evaluations of Steinbeck's use of biological and animal metaphors concluded that the author suffered from an "obsession" with biology that minimized the significance of the human experience. Much subsequent criticism echoes these early findings. An examination of Steinbeck's migrant agricultural novels, In Dubious Battle (1936), of Mice and Men (1937), and The Grapes of Wrath (1939), suggests that in fact the author's use of biological and animal imagery aids in defining and enhancing the human experience. Such imagery places humankind on an evolutionary spectrum that affirms our inherent ties to the nonhuman community, while concurrently focusing attention on the struggle of spiritual, political, and community values that are unique to the human animal. These three novels together show a progression of the human spirit that is inseparable from biological realities and relationships with nonhuman animals. These relationships delineate the need for a specifically human community that encourages its members to achieve their own individuality through participation in group decisions that affect their lives. Thus the biological influence in

Steinbeck's fiction does not detract from his human characters, but rather enhances their struggle to realize what it means to be a human being. Critics who fault Steinbeck for the inclusion of animals and biological references in his fiction usually fail to exhibit an understanding of the philosophy of which Steinbeck writes. They instead view nonhuman animals as objects of derision or sentimentality, and by definition their inclusion lowers the quality of literature produced. Many critics associate any use of animals or biological metaphor with the more negative connotations of "animalism," a term used to isolate the negative drives of human beings to the realm of the nonhuman animal, which in turn denies the existence of a harmonious duality between our two natures, physical and intellectual, and instead demands that the intellectual element of ourselves conquer and dominate the existing residual atavistic urges. Steinbeck, however, writes of what he views as an underlying reality of human nature, neither bad nor good in itself, but simply existing. Charles Child Walcutt appropriately expresses Steinbeck's philosophy as one that explores "the realities of nature and spirit, which have their fusion in human experience"(264).

Those who fault Steinbeck for his use of biological and animal imagery are unable to grasp the role this imagery plays in the author's vision of human nature. Their own prejudice against Steinbeck's biological

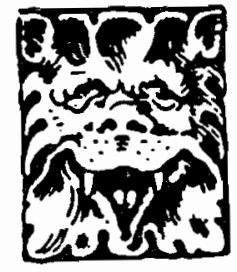


interest obscures a more holistic vision that allows for Steinbeck's use of the biological as a tool with which to present the many-sided complexities of our species.

Soine critics, such as Edınund Wilson and Frederick Hoffman, seem to assume that Steinbeck's use of the biological indicates a static view of human nature represented through simplistic rendering of nonhuman animals. From this perspective, human beings are no more than a sophisticated incarnation of animal drives and instincts, devoid of the nobler aspects that can characterize our species. Some critics fault Steinbeck for their own inference taken from his work: if the human struggle is "accompanied and parodied all the way by animals" (Wilson 231), then the author must not respect the dignity and importance of our own species. Human beings in Steinbeck's fiction, says Wilson, are no more than "lemmings, as grass that is left to die" (237).

Steinbeck's interest in biology is further criticized by Frederick Hoffman, who believes Steinbeck's "curiosity about the behavior of small animals" to be self-indulgent:

Though Steinbeck has the curiosity of his scientists, he has neither the need nor the desire for their disciplines. The curiosity is thus essentially self-indulgent; it betrays many of his fictional plans and reduces others to the level where he asks us not only to view the human as animal nature but to believe in him as such. (149)

An examination of the three novels reveals that Steinbeck's use of biological and animal imagery aids more in defining, not obscuring, the human experience. By acknowledging the existence of a "core" animal nature found in all human beings, Steinbeck reminds us, writes Pascal Covici, Jr., that, "human beings... have consciousness, choice, and awareness as animals do not. Yet people are also animals" (Introduction xvii). Acknowledgment of this element of our nature strengthens Steinbeck's philosophy, as it explores not only unique human characteristics, but also factors common to both humans and nonhumans, thus encouraging the emergence of a fuller definition of human nature than would otherwise exist.

The three novels develop the human journey from an inability to function as individuals to a harmony between individual and group. Using biological and animal imagery, Steinbeck follows the struggle of an emerging human dignity and a sense of direction and purpose. The three novels use biological and animal imagery to show a progression towards realizing the uniqueness of our species. Steinbeck views the unity of people, nonhuman animals, and the environment as a crucial factor in human development; his use of animals in these novels establishes the evolutionary background that frames human events. In Steinbeck's world, human beings do not operate on a plane above other life forms; they function as an extended and sophisticated species that retains an animal nature within. This nature is an integral reality that, once understood and accepted, aids in the journey toward a uniquely human spiritual fulfillment. This journey is explored, with increasing degrees of success, in the three novels.

Much of Steinbeck's philosophy can be traced to his interest in and experience with marine biology, the essence of which appeared in 1941 as The Sea of Cortez, a collaborative effort between Steinbeck and marine biologist Edward F. Ricketts. One concept from this work that plays a significant role in shaping Steinbeck's fiction is "group-man," which is based on the author's biological observations that any individual is also a part of a larger life form. He observes in The Sea of Cortez:

There are colonies of pelagic tunicates which have taken a shape like the finger of a glove. Each member of the colony is an individual animal, but the colony is another individual animal, not at all like the sum of its individuals.... Here are two animals, and yet the same thing-something the early Church would have been forced to call a mystery. (196)

The religious implications of Steinbeck's observation are further developed in a subsequent passage that expresses the unity of life in distinctly mystical terms:

It is a strange thing that most of the feeling we call religious... is really the understanding and the attempt to say that man is related to the whole thing... It is advisable to look from the tide pool to the stars and then back to the tide pool again. (SC 257)

Steinbeck places Charles Darwin alongside Jesus, St. Augustine, Einstein, and St. Francis as individuals who, 
in their own ways, "reaffirmed with astonishment the knowledge that all things are one thing and that one thing is all things all bound together by the elastic string of time" (SC 257).

While group-man is made up of individual human beings, it acts as an entity that is out of the control of those within its ranks. Used negatively, group-man obliterates the individuality of its members; used positively, the phenomenon enhances the individuality of the people involved. Group-man in itself is neither negative nor positive; it merely describes the needs and wants of a group of people acting together as one, retaining the capacity to act either for the detriment or the betterment of humankind. This inter-relation of community and individual is a biological concept that applies to many diverse species, although the human species exhibits more psychologically sophisticated versions of the relationship described.

The function of inter-related and responsible ties between community and individual is translated by Steinbeck into distinctly human circumstances. He later writes, in an essay on juvenile delinquency, of the importance of "inter-responsibility" between individuals and society, in order to make "it possible for humans to live and function together." He continues, "I believe that man is a double thing - a group animal and at the same time an individual. And it occurs to me that he cannot successfully be the second until he has fulfilled the first" (Saturday Review 22). The significance of group man as an integral element of Steinbeck's fiction is especially apparent in In Dubious Battle and The Grapes of Wrath.

The earliest of the three novels, In Dubious Battle (1936), uses the setting and tactics of agricultural strike organizers as "the symbol of man's eternal, bitter warfare with himself" (Letters 98). This novel examines human beings functioning as group man, under what Steinbeck refers to as "the phalanx theory." Based on the premises later outlined in the non-fiction Sea of Cortez, In Dubious Battle finds group man acting to deny the individuality of its members. The result is a negative application of the theory, as, according to Peter Lisca, the central characters "voluntarily renounce their individuality," and in turn exhibit a "renunciation of humanity" (Wide World 121-22). Richard Astro acknowledges that a person must use the "phalanx experience to fashion his own individuality" (125), and that in this early novel, "friendship, tolerance, and brotherly love" are impediments to the people involved
(121). While acknowledging that group man is essential for human spiritual progression, Steinbeck is quick to point out that the phalan $x$ theory can be used negatively as well as beneficially.

The following novel, Of Mice and Men, (1937), examines the friendship of two migrant agricultural workers, George and Lennie. This novel succeeds in illustrating the spirit of courage and brotherhood of which humans are capable, yet finds its central characters unable to transcend the insurmountable odds of their circumstance and environment. The message in Of Mice and Men has progressed from the wholly negative vision of In Dubious Battle, as the characters manage to embrace their humanity regardless of their inability to control the outcome or direction of their lives. Thus, Of Mice and Men is an affirmation of human commitment and development that, while extinguished by unyielding circumstance, has value in and of itself.

The use of biological imagery and animal symbolism in Of Mice and Men exhibits characteristics that both define and deny the dreams of the central characters. Lennie's uncontrollable "animalistic" tendencies negatively align him with nonhuman animals, ultimately denying his dream, which is symbolized primarily through the use of rabbit imagery. Rabbits symbolize security and the "safe place" noted by Peter Lisca (Wide World 135). The use of rabbits, mice, and puppies to represent the dream reveals the universal longing for comradeship and satisfaction within the human community. The softness and innocence of the creatures Lennie loves characteristically reveal the fragile and delicate nature of the romantic dream he clumsily, but earnestly, pursues. The significance of the dream, although never fulfilled, is its ability to unite people in their struggle to define themselves and their lives.

The unity of humankind, and the ability to transcend traditional barriers through the love and acceptance of our fellow human beings, is the central theme in Steinbeck's The Grapes of Wrath. 'This novel combines the phalanx theory, used negatively in In Dubious Battle, with the desire for human fellowship found in Of Mice and Men. The result is a struggle for survival founded on the acceptance of the individual's alignment with the animal world, signified through the replacement of traditional fundamentalist values by a non-judgmental spirit found in nature.

The will and strength of "the people," when based on compassion, is a force that cannot be broken by the difficulties presented by the physical world. Thus 
Steinbeck's people grow to understand their ability to endure, like the land tortoise, and to progress spiritually by the very fact of their continued existence in the face of oppression. The central characters in The Grapes of Wrath do not waste strength in fighting the underlying animal nature of human beings; rather, they harness this unifying force to give meaning and direction to their struggle. One by one, they discard the fundamentalist values that have separated them froin the natural world, and in doing so discover themselves as a part of nature, unified and distinct.

The progression of spirit shown in the three texts is evidenced by the inability of any main character in In Dubious Battle to achieve a sense of serenity or a feeling of unity with the world. In Dubious Battle finds the strikers not only fighting the growers, but fighting themselves as well. Their tactics of violence and coercion represent the internal chaos and inadequacies from which they seek to build a more equitable existence. The strike organizers do not attempt a genuine alliance between themselves and the strikers; instead they use the strikers to accomplish their own ends. That these ends are inherently just is a concept that is stated, but never once demonstrated, by the organizers.

The importance of community, of being a part of a larger whole, is examined further in Of Mice and Men. In this work, George and Lennie are able to achieve only a temporary and artificial sense of serenity through their dreams of how they will live in the future. However, they are aware of the unique nature of their friendship, and they know that this is what sets them off from other human beings. Their devotion to and reliance on one another, although centered on a dream, is spiritually more significant than the almost technical relationships of the strike organizers in In Dubious Battle. For although Mac is directly involved with Jim's death, he nevertheless immediately picks up his agenda, whereas the death of Lennie is suggested as forever changing George's life as well.

The individual struggle to obtain a sense of universality with the human community and the natural world is further developed in The Grapes of Wrath. The migrants in this novel begin their journey with dreams of how California will be; Ma especially imagines her family's happiness when they are established in the "white house" that symbolizes her hope. These dreams are much like those of George and Lennie, and in fact are proven false by the Joads' experience. Only through the painful and gradual destruction of this false hope does the family come to understand the real essence of human existence: the will to endure and transcend the physical barriers that keep human beings from uniting as one. Thus the "sense of brotherhood" that is denied in In Dubious Battle, and present but unable to transcend circumstances in Of Mice and Men, is allowed to flourish in The Grapes of Wrath.

The hope that the migrants will transcend their circumstances is signified by the identification of major characters, such as Casy, Tom, Ma, and Rose of Sharon, with the natural world. Their individual experiences are based on a willingness to view themselves not only as a part of the human community, but as a part of nature as well. In this way, the migrants achieve a sense of immortality lacking in the previous two novels. This is what Ma means when she tells Tom, "We're the people that live. They ain't gonna wipe us out. Why, we're the people-we go on" ( $G W 360$ ). The enduring nature of the migrants is symbolized by the tortoise, which insistently pursues its travels despite repeated interference and seemingly insurmountable barriers.

The three novels together exemplify Steinbeck's humanistic philosophy in dealing with what Walcutt calls "the themes of quest and struggle" (263). The novels each contain what Walcutt sees in "every piece of naturalistic writing":

The tension between hope and despair, between rebellion and apathy, between defying nature and submitting to it, between celebrating man's impulses and trying to educate them, between embracing the universe and regarding its dark abysses with terror. (17)

Walcutt views the issue in all three of the novels as being based on "the two great elements of American Naturalism - spirit and fact, the dem.nds of the heart and the demands of the mind" (258). These demands are recognized by Steinbeck's Nobel Prize acceptance speech, which asserts that the obligation of a writer is to "declare and to celebrate man's proven capacity for greatness of heart and spirit-for gallantry in defeat, for courage, compassion and love." Steinbeck's biological education in the methods of empirical observation ensures the tensions necessary to adequately depict the human dilemma that arises from our existence both within and beyond the natural world.

The combined forces of Steinbeck's biological background and his vision of the human animal as a 
unique part of the natural world together form a statement that encompasses the realm of the human experience. The dreams that signify the human dilemma, such as the dream of community, are indicative of the need to unify the disparate elements within our own nature. Only through an acknowledgment of our dependence on and interaction with the nonhuman world can we hope to reach the potential of our species.

\section{Works Cited}

Astro, Richard. John Steinbeck and Edward F. Ricketts. Minneapolis: University of Minnesota Press, 1973.

Covici, Pascal Jr., ed. The Portable Steinbeck. 2nd ed. New York: Viking Penguin, 1971.

Hoffman, Frederick J. The Modern Novel in America 1900 1950. Chicago: Henry Regnery Co., 1951.

Lisca, Peter. The Wide World of John Steinbeck. New Jersey: Rutgers University Press, 1958.

Steinbeck, John, and E.F. Ricketts. The Log from the Sea of Cortez 1941. New York: Penguin, 1986.

Steinbeck, John. In Dubious Battle. 1936. New York: Penguin, 1986.

-. Of Mice and Men. 1937. New York: Penguin, 1978.

—.The Grapes of Wrath. 1939. New York: Penguin, 1986.

Steinbeck, Elaine and Robert Wallsten. Steinbeck: A Life in Letters. 1975. New York: Penguin, 1981.

Steinbeck, John. "Some Thoughts on Juvenile Deliquency." The Saturday Review. 28 May 1955: 22.

Walcutt, Charles Child. American Literary Naturalism, A Divided Stream. Westport: Greenwood Press, 1956.

Wilson, Edmund. "The Boys in the Back Room." A Literary Chronicle: 1920-1950. Garden City, New York: Doubleday, 1950.

\section{Books Received}

Archie J. Bahm

AXIOLOGY: THE SCIENCE OF VALUES

Atlanta: Rodopi, 1993

foreward, $117 \mathrm{p}$, notes, works cited, indices $\$ 23.50$ paper

Lawrence Finsen and Susan Finsen

THE ANIMAL RIGHTS MOVEMENT IN AMERICA

From Compassion to Respect

New York: Twayne Publishers, 1994

illustrations, preface, $281 \mathrm{p}$, notes and references, selected bibliography, index

$\$ 26.95$ hardback $\mathbf{\$ 1 5 . 9 5}$ paper

Gary L. Francione

ANIMALS, PROPERTY AND LEGAL. WELFARISM:

"Unnecessary" Suffering and the "Humane"

Treatment of Animals

in Rutgers Law Review (46:2)

Newark: Rutgers, 1994

50p (pp. 721-770)

paper/no price stated

NAVS

PERSONAL CARE FOR PEOPLE WHO

CARE

Seventh Edition

Chicago: NAVS, 1994

208p

$\$ 4.95$ paper

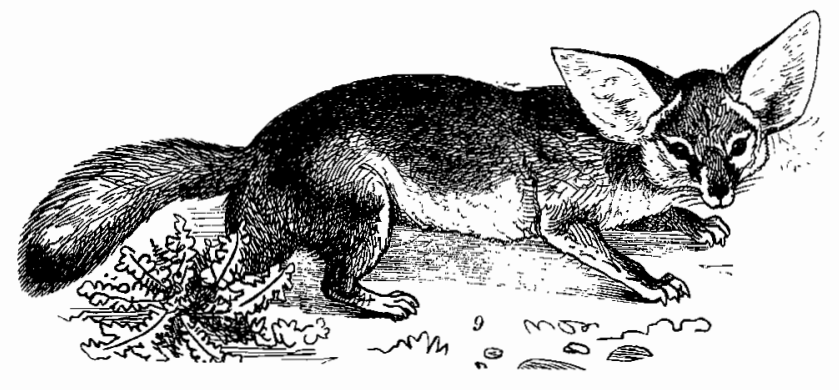

